\title{
SOSIALISASI STRATEGI MEMINIMALISIR PERNIKAHAN USIA MUDA DI SMK ASSULAMY LANGKO
}

\author{
M. ZAINAL MUSTAMIIN, ZULFAKAR, HADI GUNAWAN SAKTI \\ Program Studi Bimbingan\& Konseling FIPP UNDIKMA Mataram \\ e-mail :mzainalmustamiin@gmail.com
}

\begin{abstract}
ABSTRAK
Artikel pengabdian masyarakat ini berisikan cara pencegahan pernikahan usia dini di SMK Assulamy, Desa Langko Kecamatan Lingsar, Kabupaten Lombok Barat begitu penting dilakukan. Pernikahan usia muda berdampak negatif bagi remaja dan ketika dalam menjalani hidup berkeluarga. Alasan orang tua dulu melakukan pernikahan usia dini karena untuk menghindari zinah dan fitnah, mitos bahwa "apabila ada anak perempuan menolak untuk diajak menikah sampai 3 kali maka dirinya tidak akan laku" dan perjodohan dari orang tua mereka. Akibatnya lingkungan persepsi orang tua menjadi negatif berdasarkan pengalaman buruk yang mereka alami setelah melakukan pernikahan usia dini, yaitu pendidikan rendah, mengalami kekerasan hingga perceraian dan ibu usia muda mengalami pendarahan. Adapun strategi pencegahan pernikahan usia dini adalah orang tua menyekolahkan anak ke pondok pesantren Assulamy Langko dan himbauan dari balai nikah/KUA agar tidak nikah usia muda. Kata kunci : Lingkungan persepsi, dampak negatif, pernikahan usia muda.
\end{abstract}

\section{PENDAHULUAN}

Pernikahan usia muda menurut Undang-Undang Pernikahan No. 1 Tahun 1974 pasal 7 ayat 1 yang mengatur batas umur seorang laki-laki maupun perempuan yang akan melangsungkan pernikahan hanya diizinkan jika sudah mencapai umur 19 tahun bagi laki-laki dan bagi perempuan sudah mencapai umur 16 Tahun. Pendidikan adalah pengetahuan, keterampilan, sikap dan kebiasaan yang diajarkan oleh seorang pengajar ke peserta didik agar peserta didik memiliki kecerdasan, akhlak yang baik, kepribadian serta keterampilan yang berguna bagi diri sendiri, bangsa dan orang-orang di sekitarnya. Di lain kata juga pendidikan merupakan salah satu aspek kehidupan yang dapat ditempuh oleh setiap manusia yang menginginkannya. Karena adanya pendidikan diawali rasa ingin tahu yang ada dalam diri manusia. Dalam proses tersebut manusia akan terus menggali informasi apa yang ingin diketahui. Sehingga dari proses tersebut dapat dikatakan sebagai pendidikan. Mulai yang muda hingga tua maupun dari ekonomi yang rendah sampai menengah ke atas mempunyai hak untuk memperoleh pendidikan. Peranan pendidikan dalam kehidupan manusia tentu sangat berpengaruh. Karena didalam menjalani hidup manusia membutuhkan suatu pengetahuan maupun keterampilan untuk terus bertahan. Sehingga Pendidikan merupakan salah satu elemen penting yang akan selalu berdampingan dengan manusia. (Manan, 1989).

Salah satu aspek penunjang pendidikan masyarakat adalah dengan dibangunnya tempat yang dinamakan sekolah. Sekolah bisa diartikan sebagai suatu tempat dalam bentuk kelembagaan yang didirikan untuk mendidik anak. Tujuan didirikannya sekolah adalah untuk membuat sumber daya manusia menjadi lebih berkualitas. Seorang anak ditempatkan ke dalam sekolah untuk dapat memperoleh ilmu yang disalurkan oleh guru. Sekolah memiliki sistem tentang pendidikan yang didasari oleh ilmu pengetahuan. Penggolongan sekolah di Indonesia terbagi dalam 2 kriteria, yaitu negeri dan swasta. Sekolah negeri dapat diartikan sebagai sekolah yang dioperasikan oleh pemerintah, mulai dari fasilitas sekolah, fasilitas untuk guru maupun fasilitas untuk siswa dan semua yang berkaitan dengan sekolah ditanggung pemerintah. Sedangkan sekolah swasta merupakan sekolah yang dioperasikan oleh seorang individu maupun kelompok yang berdiri sendiri, tanpa didukung dana dari pemerintah. Penggolongan Lembaga pendidikan tidak hanya sekolah saja, namun juga ada dari segi pengolahannya yang bernama madrasah dan pondok pesantren (Soegin, Gitoasmoro, 2005). Kata madrasah berasal dari Bahasa Arab yang berarti sekolah juga. Sebenarnya madrasah dalam proses 
pembelajarannya tidak berbeda jauh dengan sekolah umum. Namun terdapat perbedaan dari segi kultur di lingkungan sekolah. Karena madrasah merupakan tempat pendidikan yang menitikberatkan pada ruang lingkup agama Islam. Madrasah sebelumnya adalah pecahan dari pondok pesantren, namun lebih luas sistem ilmu pengetahuannya. Munculnya madrasah merupakan suatu proses kemajuan dalam kebudayaan Islam untuk menyebarluaskan agama. Tingkatan sekolah menurut madrasah adalah Raudhatul Athfal, Madrasah Ibtidaeiyah, Madrasah Tsanawiyah dan Madrasah Aliyah Maksum,1999). Setelah itu juga terdapat Lembaga pendidikan yang pengajaran agama Islam memang menjadi fokus pembelajaran yaitu pondok pesantren. Pondok pesantren dapat diartikan suatu tempat yang memiliki sistem pendidikan yang lebih keislaman. Jika sekolah terdapat guru dan murid, maka pada pondok pesantren terdapat sebutan kyai sebagai guru dan santri sebagai murid. Bentuk hubungan antara Kyai dengan santri juga berbeda dari guru dengan murid. Karena di dalam pondok pesantren mereka sudah seperti orang tua dan anak. Dua elemen itu akan terus saling mendukung hingga menemukan atau menguasai agama Islam setinggi mungkin. Pondok pesantren juga merupakan salah satu Lembaga pendidikan tertua yang ada di Indonesia. Sehingga dapat diartikan bahwa pondok pesantren merupakan suatu Lembaga di bidang pendidikan yang memiliki sejarah panjang (Herman, 2013).

Lembaga pendidikan sekolah, madrasah dan pondok pesantren merupakan fasilitas dari pemerintah atau pihak swasta untuk membantu dalam proses perkembangan anak di Indonesia. Sehingga hal tersebut harus dimaksimalkan sebaik mungkin guna mencerdaskan anak bangsa. Dalam hal memaksimalkan fasilitas yang telah disediakan, tentunya seorang anak harus mendapat bimbingan dari orang tua. Orang tua memiliki peran yang sangat vital didalam perkembangan anak. Karena sebagai orang tua sudah sewajarnya untuk menyekolahkan anaknya demi perkembangannya. Peran penting orang tua didalam perkembangan anak salah satunya adalah berkaitan dengan pemilihan Lembaga pendidikan (Mesiono, 2013).

Berdasarkan kajian yang terkait dengan temuan penelitian sebelumnya menunjukkan bahwa perlunya strategi dalam mengatasi permasalahan tentang pendidikan. Permasalahan tersebut adalah mengenai pernikahan usia dini. Cara mengatasi adalah dengan memasukkan anak ke pondok pesantren. Strategi tersebut didasari dari lingkungan perseptual yang ada disekitarnya. Lingkungan perseptual tersebut di dalamnya terdapat pihak orang tua, anak dan tokoh lain yang ikut berperan serta dalam proses terbentuknya strategi. Maka dari itu penelitian yang belum dilakukan adalah terkait dengan cara meminimalisir angka pernikahan usia dini. Penelitian tentang "strategi pencegahan pernikahan anak di SMK Assulamy, Desa Langko, Kecamatan Lingsar, Kabupaten Lombok Barat" diharapkan bisa menjadi jalan keluar atas masalah mengenai rendahnya pendidikan masyarakat desa. Masalah tersebut salah satunya diakibatkan pernikahan usia dini yang masih sering terjadi di beberapa daerah pelosok Indonesia.

\section{METODE PENGABDIAN}

Metode yang digunakan dalam penelitian tentang "strategi meminimalisir pernikahan usia muda di SMK Assulamy, Desa Langko, Kecamatan Labuapi, Kabupaten Lombok Barat adalah metode etnografi. Metode tersebut digunakan agar memperoleh data kualitatif. Etnografi merupakan suatu tulisan atau laporan mengenai kehidupan suku bangsa yang kemudian ditulis oleh seorang antropolog setelah melakukan penelitian di lapangan. Etnografi adalah jenis metode penelitian yang diterapkan untuk mengungkap makna sosio-kultural dengan cara mempelajari keseharian pola hidup dan interaksi kelompok sosio-kultural (culture-sharing group) tertentu dalam ruang atau konteks yang spesifik. Seorang etnografer tak hanya mengamati namun juga berupaya untuk menyatu dalam kehidupan kultural suatu kelompok masyarakat yang diteliti. Metode Etnografi dalam penelitian ini berfungsi untuk memahami lingkungan perseptual \& perilaku orang tua dalam pendidikan anak ditengah masalah pernikahan usia dini. Permasalahan tersebut memicu munculnya tindakan berupa strategi orang tua terhadap pencegahan pernikahan usia dini yang dikaitkan dengan pendidikan anak. 
Pencarian mengenai lingkungan persepsi dan perilaku ini dapat ditemukan dengan cara menanyakan beberapa pertanyaan terkait dengan permasalahan yang menjadi fokus penelitian kepada masyarakat sekitar.

Setelah itu peneliti akan menemukan seseorang yang dianggap dapat memenuhi kriteria untuk menjadi informan dari masalah yang diteliti. Informasi yang didapat juga dilengkapi fasilitas seperti recorder handphone dan catatan buku untuk mendokumentasikan data yang telah didapat selama di lapangan. Sehingga selama penelitian di lapangan mendapatkan data yang akurat (Spradley, 2007). Pemilihan peneliti memasukkan Pondok Pesantren Assulamy dalam gambaran umum lokasi dikarenakan beberapa orang tua pada lokasi penelitian memasukkan anaknya ke sana. Sehingga gambaran umum yang ada dapat memberikan tambahan data mengenai alasan orang tua memasukkan anaknya ke pondok pesantren tersebut.

Dari hasil penelusuran yang ada beberapa fakta dilapangan menunjukkan angka pernikahan di usia muda di pondok pesantren SMK Assulamy Langko. Sejak Covid 19 0\% akan tetapi desa hanya Dengan demikian melalui kegiatan pengabdian masyarakat yang dilakukan di SMK Assulamy Langko Kecamatan Lingsar Kabupaten Lombok Barat. Tim pengabdian merasa perlu untuk melakukan sebuah kegiatan Sosialisasi meminimalisir Pernikahan usia muda.

Metode kegiatan pelaksanaan pengabdian di bagi menjadi beberapa tahap sebagai berikut:

\section{Koordinasi Kegiatan}

a. Sosialisasi dan pendekatan dengan kepala sekolah dan guru-guru dan siswa siswi di MA Assulamy Langko Kabupaten Lombok Barat .

b. Sosialisasi dan persiapan kegiatan pengabdian

\section{Pelakasanaan}

a. Pemberian Materi

Kegiatan ini meliputi penyampaian dasar teoritis tentang sebagai berikut:

1. Teori Strategi meminimalisir pernikahan usia muda

2. Langkah langkah meminimalisir pernikahan usia muda

\section{Evaluasi}

Di dalam kegiatan ini tim pengabdian akan meminta semua guru untuk selalu menyampaian danfak negatif dari nikah usia muda terhadap materi sosialisasi yang diberikan kepada peserta yang sesuai dengan kompetensi guru masing-masing dalam pengampu mata pelajaran. Kegiatan ini dilakukan untuk mengetahui danfak negatif usia muda terhadap peserta kegiatan tersebut.

\section{HASIL DAN PEMBAHASAN}

Pelaksanaan pengabdian masyarakat yang dilaksanakan pada hari Senin tanggal 16 Maret 2020 pukul 08.00 Wita sampai dengan 12.00 Wita bertempat di SMK Assulamy Langko Kabupaten Lombok Barat. Tema kegiatan ini adalah Sosialisasi Strategi Meminimalisir Pernikahan Usia Muda. Tujuan kegiatan ini untuk dapat meningkatkan pemahaman kepada guru dan siswa tentang danfak negative pernikahan usia muda. Kegiatan ini diisi oleh bapak M. Zainal Mustamiin, M.Pd sebagai pemateri, Dr Hadi Gunawan Sakti, M.Pd. Dr Zulfakar selaku tim anggota. Kegiatan pengabdian dibuka langsung oleh Kepala Sekolah SMK Assulamy Lagko. Kegiatan dihadiri oleh Semua Santri yang terdiri dari guru-guru dan para siswa/Siswi .

Kegiatan pokok dalam pengabdian yang dilakukan di SMK Assulamy Langko Kabupaten Lombok Barat yakni memberikan Sosialisasi tentang Strategi meminimalisir danfak negatif pernikahan usia muda . Kegiatan Sosialisasi ini dipandu langsung oleh M. Zainal Mustamiin, M.Pd selaku pemateri dan Dr Zulfkar., Dr Hadi Gunawan Sakti, M.Pd. Adapun rincian materi yang diberikan adalah berupa dampak negatif pernikahan usia muda.

Berdasarkan data dari DP3AP2KB Kabupaten Lombok Barat tercatat 512 kasus pernikahan usia dini sejak Januari - Oktober 2020. Data ini menunjukkan bahwa jumlah angka 
pernikahan Anak di bawah umur 18 tahun sangat memprihatinkan. Urutan tertnggi kasus ini terdapat di Kecamatan sekotong disusul lingsar dan narmada. Oleh karena penulis menelusur dari berbagai sumber terutama pada objek penelusuran di Pondok Pesantren Assulamy Desa Langko Kecamatan lingsar tergolong tinggi kedua setelah sekotong secara umum. Pada tahun 2019 tercatat sebanyak 22\% kasus ditekan dari angka 23\% di Kabupaten Lombok Barat secara umum. Dalam hal ini, penulis mengambil sampel di SMK Assulamy pada tahun 2020. Sejak pandemi covid 19, siswa SMK yang menikah dini adalah sebanyak 2 orang atau $0,06 \%$ dari jumlah siswa SMK secara keseluruhan sebanyak 76 orang yang di dominasi oleh siswa perempuan. Jika dilhat dari populsi keseluruhan siswa di Ponpes Assulamy Lagko dari jenjang SMP, MA dan SMK yang berjumlah 356 orang, maka persentase pernikahan yang terjadi adalah sebnyak $0,14 \%$. Jadi, kesimpulan para tim pengabdan pada masarakat Undikma Mataram yang mengadakan penelusuran data adalah angka pernikahan termasuk kategori angka darurat pernikahan di usia muda sehingga tim pengabdan konsen menjelaskan materi sosialisasi danpak pernikahan usia muda.

Dalam hal ini tim pengabdian menjelaskan strategi meminimalisir dampak negatif pernikahan usia muda pokok-pokok materi itu sampai selesai, tim pengabdian mengadakan evaluasi kepada guru dan siswa siswi yang hadir dengan masing-masing rata rata sudah memahami materi yang di sampaikan dapat di tarik kesimpulan bahwa hampir semua dapat memahami tentang materi meminimalisir pernikaha usia muda keluaraga besar SMK Assuulamy telah memahami danfak negatif nikah di usia muda apa yang sudah di sampaikan tim pengabdian.

Berikut adalah data dari beberapa informan terkait alasan mereka melakukan pernikahan usia dini sebagai berikut:

\section{1) Menghindari fitnah dan perbuatan zinah}

Faktor yang pertama adalah untuk menjaga nama baik keluarga, yakni menghindari fitnah. Hal tersebut disebabkan akan muncul pikiran negatif apabila ada sepasang laki-laki dan perempuan dalam satu lokasi. Tentunya akan terlihat aneh apabila ada 2 orang lawan jenis yang sedang berdua. Meskipun urusan mereka karena masalah pekerjaan atau yang lainnya. Namun pandangan masyarakat sana yang memang semuanya beragama islam tentu hukumnya adalah tidak memperbolehkan seseorang yang belum muhrim untuk berdekatan dengan lawan jenis.

Sehingga persepsi masyarakat dalam menghidari fitnah tertanam dalam pikirannya dan membuat sesuatu agar tidak mendapatkan hal tersebut. Sebagai manusia tentunya akan merasa senang apabila kita bisa dekat dengan lawan jenis, apalagi disaat kita sedang mengalami perasaan suka yang begitu mendalam. Demi bisa melakukan hal tersebut di wilayah tersebut tentu dilarang jika dekat lawan jenis yang bukan muhrim. Sehingga salah satu cara agar mereka bias selalu dekat dengan lawan jenis adalah dengan menikahi orang yang disuka. Dengan melakukan cara tersebut, mereka akan terhindar dengan pikiran buruk tau fitnah dari orang lain.

\section{2) Mitos yang berkembang pada masyarakat sekitar}

Berbagai macam budaya yang tersebar dari Sabang sampai Merauke. Tentunya akan banyak sekali budaya yang ada di nusantara ini. Budaya tersebut adalah peninggalan dari masa lalu yang masih digunakan atau dipercaya sampai sekarang. Salah satu budaya tersebut kadang berkaitan dengan adanya mitos. Intinya hal tersebut seperti sebuah aturan yang tidak tertulis yang mengharuskan masyarakat tersebut mematuhinya. Masyarakat Desa Langko juga masih percaya dengan mitos bahwa apabila salah satu dari pihak laki-laki atau perempuan menolak untuk dinikahkan sampai 3 kali, maka mereka akan menyendiri selamanya. Tentu hal tersebut menjadi semacam gangguan yang membuat setiap individu untuk harus siap melakukan pernikahan kapan saja, termasuk nikah di usia yang masih sangat muda sekalipun. Karena mereka akan merasa takut menolak apabila ada seseorang yang ingin menikahinya. Padahal disisi lain mereka belum siap untuk melakukan pernikahan.

Hal itulah yang di alami salah satu informan yang ada di Desa Lagko yang akrab disapa 
Arjuna seorang mantan kepala desa langko. Informan bercerita bahwa dulunya memang diminta oleh pihak laki-laki untuk segera melakukan pernikahan. Namun wanita yang identik dengan rambut panjang tersebut merasa belum siap untuk melakukan pernikahan. Alasan belum siap tersebut juga dikarenakan usia yang masih terlalu muda. Laki- laki yang sekarang menjadi suaminya tersebut seperti tidak mengenal kata menyerah untuk terus mendekatinya. Hingga untuk yang ketiga kalinya pihak laki-laki meminta untuk segera melakukan pernikahan.

Akhirnya si weny yang percaya mengenai mitos yang berkembang dimasyarakat mau untuk melakukan pernikahan diusia yang masih terlalu muda, yaitu 10 tahun. Sehingga dari data yang ditemukan dilapangan dapat disimpulkan bahwa penduduk Desa Langko masih ada yang percaya mengenai mitos yang berkembang dari dulu, salah satunya Mbak Nina. Namun ketika peneliti menanyakan bagaimana mitos tersebut ada, informan sendiri tidak bisa menjawabnya. Mbak Dewi hanya mengatakan bahwa mitos tersebut sudah ada sejak nenek moyang mereka ada di Desa Langko.

\section{3) Dampak negatif pernikahan usia muda}

Persoalan yang tengah terjadi pastinya akan menimbulkan dampak. Dampak tersebut bisa menjadi sesuatu yang bersifat positif dan bisa juga bersifat negatif. Dalam masalah yang terjadi di Desa Langko yaitu permasalahan pernikahan usia dini memiliki dampak yang bersifat negatif. Hal tersebut juga disadari oleh petugas kesehatan yang ada di Desa Langko yang bernama pak Heri. Beliau mengatakan bahwa dampak negatif yang diakibatkan pernikahan usia dini cukup membahayakan. Karena itu akan mencakup masalah kesehatan dan juga Pendidikan anak. Sehingga resiko dari pernikahan usia dini tidak hanya dirasakan sendiri, tetapi juga anaknya nanti. Apabila dilihat dari segi kesehatan dan Pendidikan mereka yang melakukan pernikahan usia muda, nantinya akan timbul efek negatifnya. Masalah dari segi kesehatan yang ditakutkan adalah kondisi ibu maupun anak pada saat kelahiran nanti.

Menurut data yang ada di lapangan, beberapa informan yang merupakan pelaku pernikahan usia dini memiliki Pendidikan yang rendah. Hal tersebut juga bisa dilihat dari sub bab sebelumnya mengenai pendidikan terakhir informan yang melakukan pernikahan usia dini. Dimana kebanyakan dari mereka yang melakukan pernikahan usia dini pendidikan terakhirnya adalah lulusan SD dan SMP. Banyak dari mereka yang putus sekolah karena melakukan pernikahan. Kepala Desa Langko juga berpendapat bahwa faktor menikah usia dini merupakan salah satu penyebab rendahnya pendidikan masyarakat di Langko tersebut. Karena setelah menikah seseorang tidak memungkinkan untuk melajutkan sekolah lagi. Hal itu disebabkan mereka telah memiliki anak dan harus mengurusnya,terutama pihak wanita.

Secara umum dampak negatif yang akan diakibatkan dari pernikahan pada usia dini sebagai berikut:

\section{a) Mengalami kekerasan dan perceraian}

Dampak dari seseorang yang melakukan pernikahan usia muda selanjutnya adalah rentan mengalami pertengkaran hingga nantinya bisa berujung perceraian. Hal ini dikarenakan kedua pihak laki-laki maupun wanita memiliki ego sendiri- sendiri ketika terjadi masalah. Sehingga sifat tersebut membuat mereka berdua tidak ada yang mau mengalah. Hal itu dikarenakan mental mereka belum siap untuk menghadapi kehidupan rumah tangga. Apalagi diusia mereka yang masih sangat muda. Tentu hal yang dipikirkan tidak seperti pada seseorang yang telah matang dan siap untuk melakukan pernikahan. Ketika itu juga suami berada dirumah dan melihat Mbak Dwik sedang berbincang-bincang dengan laki-laki lain. Kemudian suaminya langsung cemburu dan mendatanginya. Tidak sampai disitu, masalah sampai berlarut-larut hingga suami Mbak Dwik dengan tega bertindak kasar kepada informan dengan memukulnya. Pada saat itulah keretakan rumah tangga yang sudah dikaruniai satu anak tersebut mulai muncul. Akhirnya Dwik sudah tidak kuat dengan tindakan suami kepada dirinya. Sehingga informan meminta cerai kepada suaminya. Tentu hal tersebut begitu menyesalkan karena pada awalnya mereka terlihat bahagia namun setelah berjalan semua yang terjadi tidak seperti yang diinginkan. Informan 
sendiri juga menjelaskan bahwa dia tidak menyesal dengan perceraian yang dilakukan dengan suami. Penyesalan yang dirasakan dari informan adalah terlalu cepatnya dia mengambil keputusan untuk menkah diusia yang masih begitu muda.

\section{b) Ibu usia muda mengalami pendarahan}

Dampak yang akan terjadi ketika melakukan pernikahan usia muda tidak hanya akan menyebabkan Pendidikan pelaku tersebut akan berhenti. Namun hal ini lebih ke masalah kesehatan pasangan tersebut, terutama bagi pihak wanita. Perlu kita ketahui bahwa sistem reproduksi yang ada pada pihak wanita terdapat masa dimana siap untuk hamil dan melahirkan. Jika tidak siap, hal tersebut akan membahayakan calon ibu dan juga bayinya ketika mengalami proses kehamilan hingga melahirkan. Masa remaja adalah masa dimana dimulai transisi seorang anak menjadi seorang remaja. Hal itu ditandai dengan munculnya ciri-ciri pubertas yang dialami pihak laki-laki maupun wanita. Cukup banyak dampak yang diakibatkan hamil diusia muda, diantaranya dapat menyebabkan tekanan darah tinggi. Hal ini terjadi karena sel telur pada wanita masih belum kuat untuk proses kehamilan sehingga menyebabkan tekanan darah yang terjadi tidak seperti biasanya. Tekanan darah tinggi atau hipertensi dapat menyebabkan pendarahan ketika proses kehamilan.

\section{4) Strategi Meminimalisir Pernikahan Usia Muda}

Penjelasan mengenai strategi meminimalisir pernikahan usia muda diantaranya diawali dengan bentuk lingkungan persepsi tentang pendidikan pondok pesantren. Lingkungan persepsi tersebut berasal dari orang tua yang menyekolahkan anaknya k pondok pesantren dan anak yang bersekolah di pondok pesantren. Kemudian penjelasan berikutnya adalah mengenai bentuk perilaku pencegahan dari orang tua dan juga himbauan dari KUA dan Pemeintah. Perilaku meminimalisir yang dilakukan adalah menyekolahkan anaknya ke pondok pesantren. Sedangkan dari KUA menghimbau agar masyarakat menunggu diusia yang sudah siap untuk menikah, seperti selepas SMA. Setelah itu adalah penjelasan mengenai pengambilan keputusan orang tua yang memilih Pondok Pesantren Assulamy sebagai tempat sekolah bagi anaknya. bentuk strategi modin desa setempat terhadap pencegahan pernikahan usia dini. Pemilihan tersebut juga berdasarkan alasan-alasan yang berbeda dari setiap informan orang tua dan anak. Terakhir adalah hasil dari strategi terhadap meminimalisir yang dilakukan oleh KUA maupun orang tua. Hasil ini dilihat berdasarkan perbandingan antara tingkatan pendidikan antara orang tua yang dulunya nikah muda dengan anak mereka yang sedang menjalani pendidikan. Selain itu juga melakukan perbandingan mengenai pekerjaan orang tua dan anaknya.

Orang tua menyekolahkan anaknya ke pondok pesantren Lingkungan persepsi yang bersifat positif dari orang tua terhadap pondok pesantren membuat mereka memutuskan untuk menyekolahkan anaknya ketua Lembaga pendidikan tersebut.Hal tersebut juga dipengaruhi pengalaman orang tua terhadap dampak negatif yang mereka alami setelah melakukan pernikahan usia dini. Sehingga dengan menyekolahkan anaknya ke pondok pesantren setidaknya bisa mencegah mereka untuk melakukan pernikahan usia muda. Dari 5 informan, 3 diantaranya adalah orang tua yang sedang menyekolahkan anaknya ke pondok pesantren. Informan yang pertama adalah Ibu Suhartini. Sekarang informan tersebut sedang menyekolahkan anaknya yang masih berumur 22 tahun ke pondok pesantren. Sejak dari SMP anak dari Ibu hariati disekolahkan ke pondok pesantren.

\section{5) Himbauan dari Penghulu/P3/KUA}

Penghulu dapat dikatakan sebagai orang yang menjadi penengah pada saat kedua pihak antara laki-laki dan wanita ketika melakukan pernikahan. Tugas Penghulu selain mengurus masalah pernikahan adalah mendata kematian maupun perceraian. Sehingga modin dianggap sebagai tokoh yang penting di dalam kehidupan masyarakat. Pengaruh Penghulu dalam suatu wilayah, khususnya daerah pedesaan sunggah sangat vital. Maka dari itu seorang penghulu memiliki peran penting dalam meminimalisir dari dampak pernikahan dini. Maka tugas 


\section{COMMUNITY : Jurnal Pengabdian Kepada Masyarakat Vol. 1 No. 1 Mei 2021 e-ISSSN : 2797-0159 | p-ISSN : 2797-0574}

penghulu sangatlah berat dlam melaksanakan tugas dan kewajibanya. Hal itu dikarenakan tugas Penghulu tidak semudah yang dibayangkan. Penghulu juga memiliki semacam peraturan yang harus ditaati apabila ingin menggunakan jasanya. Aturan tersebut mencakup segala hal yang berkaitan dengan pernikahan, kematian maupun perceraian. Penghulu yang ada di Desa Langko memiliki cara tersendiri agar angka pernikahan usia dini tidak begitu tinggi. Karena beliau menyadari bahwa angka pernikahan usia dini di desanya cukup tinggi. Strategi yang dilakukan adalah berkaitan dengan meninggikan kualitas Pendidikan yang ada disana. Karena salah satu faktor yang menyebabkan banyaknya masyarakat setempat memiliki Pendidikan rendah adalah pernikahan usia dini. Modin Desa Langko adalah bapak Jamhur yang merupakan salah satu tokoh masyarakat disana. Cara penghulu tersebut dalam meminimalisir pernikahan usia muda adalah bagi siapa yang ingin melakukan pernikahan dirinya menghimbau untuk memiliki ijazah minimal SMA terlebih dahulu. Maksudnya adalah pada usia selepas SMA dianggap sebagai saat yang cukup dan siap untuk melakukan pernikahan. Hal itu dilakukan agar untuk mengurangi angka pernikahan dini di Desa Langko. Dengan strategi tersebut tentunya diharapkan dapat menuntun para masyarakat yang ingin menikah untuk segera menyelesaikan sekolah SMA terlebih dahulu.

\section{KESIMPULAN}

Dapat disimpulkan menunjukkan bahwa beberapa orang tua sudah sadar akan bahaya dari pernikahan usia dini. Kesadaran tersebut muncul setelah mereka mengalami kejadian buruk tidak lama setelah melakukan pernikahan usia dini. Kejadian buruk tersebut berupa tidak bisa melanjutkan sekolah, mengalami kekerasan hingga perceraian dan pendarahan pada ibu yang hamil diusia muda. Hal tersebut seakan menjadi pembelajaran bagi mereka agar tidak langsung memutuskan sesuatu tanpa berpikir Panjang, seperti melakukan pernikahan. Beberapa orang tua yang memiliki persepsi negatif mengenai pernikahan usia dini menunjukkan bahwa mereka ingin melakukan pencegahan terhadap hal tersebut. Pencegahan itu dimaksudkan terutama untuk anaknya agar tidak melakukan pernikahan usia dini.Menyekolahkan anaknya ke Pondok Pesantren Assulamy adalah strategi pencegahan pernikahan usia dini dari orang tua. Orang tua menilai dengan menyekolahkan ke pondok pesantren, anaknya bisa fokus belajar dan dapat menempuh pendidikan lebih tinggi daripada orang tua. Angka ini sangat memprihatinkan terlhat sejah tahun 2020 angka itu terus mengalami peningkatan yatu dari Pada tahun 2019 tercatat sebanyak 22\% kasus ditekan dari angka 23\% di Kabupaten Lombok Barat secara umum. Sedangkan di kecamatan lngsar desa langko tercatat sejak covid 19 mengalam peningkatan berada pada angka $0,06 \%$ dari jumlah siswa SMK secara keseluruhan sebanyak 76 orang yang di dominasi oleh siswa perempuan. Jika dilhat dari populsi keseluruhan siswa di Ponpes Assulamy Lagko dari jenjang SMP, MA dan SMK yang berjumlah 356 orang, maka persentase pernikahan muda yang terjadi adalah sebnyak $0,14 \%$ angka yang sangat memprihatinkan

Selain itu orang tua menganggap pondok pesantren menjadi tempat yang aman bagi mereka. Aman yang dimaksudkan adalah terkait dengan kondisi jalan dan lingkungan sekitar. Kemudian juga tidak ingin anaknya memikirkan hal yang tidak penting seperti pacaran. Karena pacaran sendiri bisa memicu munculnya pernikahan usia dini. Lingkungan persepsi yang bersifat positif tentang pondok pesantren membuat beberapa informan menyekolahkan anaknya ke pondok pesantren. Pemilihan pondok pesantren tersebut juga dikarenakan beberapa alasan, diantaranya fasilitas yang menurut mereka lengkap, biaya yang tidak mahal dan juga karena tetangga mereka menyekolahkan anaknya di sana. Strategi pencegahan usia dini selanjutnya adalah melaksanakan himbauan dari KUA setempat pada orang tua yang diharapkan tidak melakukan pernikahan usia dini dan lebih berfokus untuk melanjutkan pendidikan anak.

\section{DAFTAR PUSTAKA}

Abdullah Faisal, Pandangan Ulama Dayah Terhadap Pernikahan Anak usia Dini (Skripsi yang tidak di publikasikan), Banda Aceh:Fakultas syar’iyah,UIN Arranirry 2014. 
Manan, I. (1989) Antropologi Pendidikan. Jakarta: Departemen Pendidikan dan Kebudayaan Direktorat jenderal Pendidikan Tinggi Proyek Pengembangan Lembaga Pendidikan Tenaga Kependidikan.

Mesiono, M. P. (2013) „Raudhah", Jurnal Pendidikan Anak Usia Dini, 1.

Muharil, Perkawinan Anak di Bawah Umur dan Dampaknya Terhadap Keluarga Sakinah Skripsi yang tidak di publikasikan).(Banda Aceh Fakultas Syar’ah 2014.

Soegiin, Gitoasmoro (2005) „Peran Pendidikan Nonformal Dalam Realisasi Wajib Belajar Pendidikan Dasar", Peran Pendidikan.

Muchit A. Karim \& Selamet, Menelusuri makna di balik fenomena perkawinan di bawah umur dan perkawinan tidak tercatat, Cet.1, Jakarta: Badan Litbang dan Diklat, Kementerian Agama R.I, 2013.

Mubasyaroh. 2016. "Analisis Faktor Penyebab Pernikahan Dini dan Dampaknya bagi Pelakunya”. Jurnal Yudisia STAIN Kudus, Vol. 7, No.2, hlm. 285 - 411.

Fadlyana, Eddy dan Shinta Larasaty. 2009. "Pernikahan Usia Dini dan Permasalahannya". Sari Pediatri, Vol. 11, No. 2. hlm 136 - 140. 